\title{
銀含有ガラスの発色に対する多原子価イオン および紫外線照射の影響について
}

\author{
銀含有ガラスの発色に関する研究（第 1 報）
}

\section{境野照雄 \\ (東京工業大学)}

\author{
Effect of the Addition of Multivalent lons and the Irradiation of U.V. \\ Rays on Colour Development in Silver-containing Glasses. \\ Studies on Colour Development in Silver-containig Glasses, (I) \\ By Teruo SAKAINO \\ (Tokyo Institute of Technology, Tokyo)
}

\begin{abstract}
It is known that the addition of $\mathrm{SnO}, \mathrm{Sb}_{2} \mathrm{O}_{3}, \mathrm{Fe}_{2} \mathrm{O}_{3}$ and $\mathrm{CeO}_{2}$ etc., the oxides of multivalent elements, promote the development, and stabilization of the colloidal colours obtained by reheating the glasses containing $\mathrm{Au}, \mathrm{Ag}$, and $\mathrm{Cu}$. In order to know the mechanism of the function of so called thermoreducing agents, or sesitizers, in developing colours a series of experiments has been carried out taking Ag-glass as an example.

The composition of base glass was $\mathrm{Na}_{2} \mathrm{O} 18.0, \mathrm{CaO} 8.5, \mathrm{Al}_{2} \mathrm{O}_{3} 1.5$, and $\mathrm{SiO}_{2} 72.0 \%$ by weight, and to which $0.025 \mathrm{gram}$ atom of $\mathrm{Ag}_{2} \mathrm{O}$, and 1 or 4 gram atoms of 11 thermoreducing agents, i.e., $\mathrm{TiO}_{2}, \mathrm{~V}_{2} \mathrm{O}_{5}, \mathrm{Cr}_{2} \mathrm{O}_{3}, \mathrm{MnO}_{2}, \mathrm{FeC}_{2} \mathrm{O}_{4} \cdot 2 \mathrm{H}_{2} \mathrm{O}, \mathrm{CoO}, \mathrm{NiO}, \mathrm{SnO}, \mathrm{Sb}_{2} \mathrm{O}_{3}$, $\mathrm{Ce}_{2}\left(\mathrm{C}_{2} \mathrm{O}_{4}\right)_{3}, \mathrm{UO}_{2}\left(\mathrm{NO}_{3}\right)_{2}$ were added.

The 20 glass samples prepared from the different combinations of sensitizers given above were subjected to the combinations of following heat treatments :

1) Holding for 10 minutes at $650^{\circ} \mathrm{C}$ followed, respectively, by cooling to $400^{\circ} \mathrm{C}$ in 2 hours at constant rate and then quenching to ordinary temperature.

2) Irradiation by ultraviolet rays.

3) Preheating at $800^{\circ} \mathrm{C}$ for 10 minutes.

The spectral transmission between 250 and $750 \mathrm{~m} \mu$ of the specimens which have developed colours by applying the combined treatments of above three types were measured, and the results were compared with the transmission of those containing no sensitizer and have passed through the exactly the same pretreatments.

Within the scope of the present experiments it has been shown that the ions of Cr, Co, $\mathrm{Sn}$ act effectively in the colour development by heat treatment, while those of $\mathrm{Cr}, \mathrm{Fe}, \mathrm{Sn}$, $\mathrm{Sb}, \mathrm{Ce}$ are effective in developing by ultraviolet irradiation.

Considering that these effects may be ascribed to the increase of the concentration of atomic silver, $\mathrm{Ag}^{\circ}$, during the heat treament, where the constants of the equilibria, such as

$$
\begin{aligned}
& \mathrm{Ag}^{\circ} \rightleftarrows \mathrm{Ag}^{+} \\
& \mathrm{M}^{+} \rightleftarrows \mathrm{M}^{2+},
\end{aligned}
$$

in which $\mathrm{M}$ is a multivalent element, are highly temperature dependent, the author was able to explain satisfactory the function of the thermoreducing agents, or sensitizers, by the difference of the temperature dependency of the equilibria.
\end{abstract}

\section{I. まえがき}

古くから工坛用ガラスの分野では，金，銀，銅などの 金属をガラスの着色剂として利用するととが広く新てな われており，金による紫，青，赤，銀による黄，橙，緑， および銅による赤などの着色が，ガラス中に分散してい る上記それぞれの金属のコロイド状の微細な結晶によっ て，選护的に入射光か吸収され，また散乱されるとと によるものであるととも，一般に知られているととろで
ある・しかし，最近になって，ガラス中に分散する，て れら金属の微結晶が，单にガラスの着色としてではな く，超顕微鏡的微結晶からなるセラるクス，すなわちデ

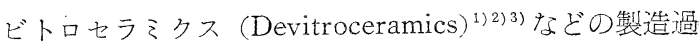
程のひとつに，ガラス自体を均等に絬晶化させるための 結晶核として利用されるようになり，再びガラス中に沶 ける，これら金属の析出現象に興味の目が注がれるよう になった。 
前述のような意味で，乙れらの金属をガラスの着色剤 之して用いる場合には, 従来から, ガラスの発色をより いっそう容易にする目的で, 一般に酸化錫とか酸化アン チモンなどが補助剤として添加されており，またガラス 中における，てれらの金属の光化学的変化を必要とする 場合には酸化セリウムなどか加光られている。いずれに せよ，てれらの補助剤として加えられる元素に共通する ことは，それらが，いずれもガラス中で 2 種以上の原子 価をとるととのできる多原子価元素であるというととで ある。

一般に, ガラス中にあって, 多原子価元素は, 周困の 条件によって，その原子価を変え得るものと考元られて いる。このととは，とくに金，銀，銅などの金属の微結 晶を无ラス中に析出させて着色する際に利用されている $\mathrm{SnO}, \mathrm{Sb}_{2} \mathrm{O}_{3}$ などの役割に関係して, W.A. Weyl ${ }^{4)}$ な゙ によって唱觉られており, また感光性ガラスの光化学的 な過程においても，セリウム・イオンの原子価の変化住 関係して説明されている5)・だが，それらは結局，たと 壳ば次式に示すように，

$$
\mathrm{Ag}^{+}+\mathrm{M}^{+} \rightarrow \mathrm{Ag}^{\circ}+\mathrm{M}^{2+}
$$

多原子価イオン $(M)$ の原子価か增加するととによって 金属イオン $\left(\mathrm{Ag}^{+}\right)$亿価電子学与光, それ原子状態に まで還元する役目を果すものと説明されている(5)677。

また一方に抏てて,てれらの多原子価イオンの効果に つては, 上述のような還元作用以外飞, 金, 銀, 銅な ぞの金属の，ガラスに対する溶解度を增加させる作用が あるととを Weyl は主張して扔り8, その結果, それら の金属の結晶方娍長しすぎてガラスの色調の污濁するて とを防ぐ役目をも果していると考光ているが，かならず しも現象を明確に説明しているとはい壳ない。

さらに，てのようなコロイド状金属の析出によるガラ スの発色過程については，たとえば金含有ガラスについ ては Maurer の研究9が，また銀含有ガラスについては 横田らの報告 ${ }^{10}$ があり, さらに銅赤ガラスの発色温度に 関しては著者ら ${ }^{11}$ のほかにも Riedel ら ${ }^{12)}$ や沢井ら ${ }^{13)}$ が $^{2}$ それぞれ研究しているが，てれらのガラスの発色と多原 子洒イオンの举動との関係については触れるととろが少 かった。

よって, とてに基礎ガラスとして単純な $\mathrm{Na}_{2} \mathrm{O}-\mathrm{CaO}-$ $\mathrm{Al}_{2} \mathrm{O}_{3}-\mathrm{SiO}_{2}$ 系をえらび，乙机発色剂として銀を，ま た補助剤として鉄, ニッケル, コバルト等の遷移元素を 含さ種々の多原子価元素化合物を加えたガラス試料住対 して, 紫外線照射, 加熱等の種々の処理をほどしし, こ れら試料の発色の差から，銀含有ガラスの発色汸よ注 す，てれら多原子価イオンの作用を調べた。発色剤とし て，とくに銀をえらんだのは，横田ら ${ }^{10)}$ の実験にみるよ うに，ガラス中に銀の結晶か䉼出した場合に示す分光透 過率曲線が，他の金や銅の場合にくらべて単純であり，
解析しやすいためである.

本実験では，とくに，ガラス中において，同時に2 種 あるいは，それ以上の原子研をとって共存している同種 イオン間の平衡関係と，それにおよぼす温度の影響が中 心問題であり，銀のガラス中への析出現象を介して追究 し得た結果について報告する。

\section{II. 夸験とその結喿}

本研究の対象が，主としてガラス中における銀の結晶 の析出過程におよぼす種々の多原子価元素の添加の影響 にあったので, 基整ガラスとしては, 容易にガラス化 し, かつ比較的安定なものが得られるという点から, 化 学組成として, $\mathrm{Na}_{2} \mathrm{O}$ 18.0, $\mathrm{CaO} 8.5, \mathrm{Al}_{2} \mathrm{O}_{3}$ 1.5, $\mathrm{SiO}_{2}$ 72.0 (重量 \%) の4成分系をえらんだ。また，銀とと も亿加光た補助剂は, Ti, V , Cr, Mn, Fe, Co, Ni, $\mathrm{Sn}, \mathrm{Sb}, \mathrm{Ce}, \mathrm{U} の 11$ 元素で, $\mathrm{Fe}$ と $\mathrm{Ce}$ は修酸塩, またUは硝酸ウラニールを用い，他はすべて酸化物の 形で使用した。着色剂としての酸化銀は, 硝酸銀溶液に 坷性ソーダ溶液を加えて生じた沈澱を水洗し, $70^{\circ} \sim 80^{\circ} \mathrm{C}$ で数時間乾燥して造ったものを用いた。基礎ガラス用原 料法, 酸洗をした珪砂, 無水炭酸ソ一ダ, 沈降炭酸石灰, およびクロマトグラフ用アルミナである，以上すべての 原料, 薬品類は試薬特級抢よびその相当品を使用した。

各組成の原料は,メノウ乳鉢で混合, 高アルミナ質坩 堝に入れ，小型ガス炉中で，泳添 $1400^{\circ} \mathrm{C}$ で 1.5 時間 熔融し。急冷して厚さ $3 \sim 4 \mathrm{~mm}$ の板状の試料とした。 ガラスの量は $200 \mathrm{~g}$.

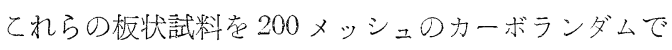
研摩して厚さ $1 \mathrm{~mm}, 7 \mathrm{~mm} \times 10 \mathrm{~mm}$ の短冊形に成形し, 熱処理によって発色したもの在, 島津製 QR-50 型光電 分光光度計で, 波長 $250 \sim 750 \mathrm{~m} \mu$ の範囲で, 分光透過 率（\%) を測定した・ただし，試料ガラスの表面は粗面 なので, 同一条件で熔融した基礎組成のガラスを, 前者 と同様に研摩して作成したもの应標準試料とし, 両片と もに，それぞれ光度計附属の石英ガラス製試料槽内に固 定し, 蒸溜水を満たして試料の表面に上る光束の散乱亿 よる損失をできるだけ防いで分光透過率の測定をおてな った。

また,カーボランダムによる研摩再峙後述のような熱 処理によって多少の影響在うけ, 表面状態か湾化するの で, 熱処理をほごこした試料の透過率を測定する際にか ぎり,カーボランダムで研摩した基礎組成ガラス試翷 を, とくに前記熱処理と同一条件で加熱し, その表面を, できるがりり測定試料之同一状態としたものをもって, 分光透過率測定用の標準試料とした。

実験に用いられた各試料の調合組成を表一 1 に一括し て示す.

これらの調合物は，すべて前述のような条件によって 
Table 1. Batch compositions of glasses.

1) Oxide-compostition of the parent glass: $\mathrm{Na}_{2} \mathrm{O} 18.0, \mathrm{CaO} 8.5, \mathrm{Al}_{2} \mathrm{O}_{3} 1.5, \mathrm{SiO}_{2} 72.0$ (wt.\%).

2) Quantity of silver oxide is represented in part to 100 parts of the parent glass, while that of each compound of multivalent element is indicated as ratio of multivalent element to silver in gram-atom.

\begin{tabular}{|c|c|c|c|c|c|c|c|c|c|c|c|}
\hline $\begin{array}{l}\mathrm{AGO} \\
\mathrm{Ag}_{2} \mathrm{O}\end{array}$ & 0.025 & & $\begin{array}{l}\mathrm{AGTi-} \\
\mathrm{Ag}_{2} \mathrm{O} \\
\mathrm{TiO}_{2}\end{array}$ & $\begin{array}{c}1 \\
0.025 \\
0.25\end{array}$ & 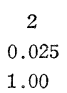 & $\begin{array}{l}\mathrm{AGV}- \\
\mathrm{Ag}_{2} \mathrm{O} \\
\mathrm{V}_{2} \mathrm{O}_{5}\end{array}$ & $\begin{array}{c}1 \\
0.025 \\
0.25\end{array}$ & $\begin{array}{c}2 \\
0.025 \\
1.00\end{array}$ & $\begin{array}{l}\mathrm{AGCr}- \\
\mathrm{Ag}_{2} \mathrm{O} \\
\mathrm{Cr}_{2} \mathrm{O}_{3}\end{array}$ & $\begin{array}{c}1 \\
0.025 \\
0.25\end{array}$ & $\begin{array}{c}2 \\
0.025 \\
1.00\end{array}$ \\
\hline AGMn- & 1 & 2 & AGFe- & 1 & 2 & AGCo- & 1 & 2 & AGNi- & 1 & 2 \\
\hline $\mathrm{MnO}_{2}$ & 0.25 & 1.00 & $\begin{array}{l}\mathrm{Ag}_{2} \mathrm{O} \\
\mathrm{FeC}_{2} \mathrm{O}_{4} \cdot 2 \mathrm{H}_{2} \mathrm{O}\end{array}$ & 0.25 & $\begin{array}{l}0.025 \\
1.00\end{array}$ & $\begin{array}{l}\mathrm{Ag}_{2} \mathrm{O} \\
\mathrm{CoO}\end{array}$ & 0.25 & $\begin{array}{l}0.025 \\
1.00\end{array}$ & $\begin{array}{l}\mathrm{Ag}_{2} \mathrm{O} \\
\mathrm{NiO}\end{array}$ & 0.25 & 1.00 \\
\hline AGSn- & 1 & 2 & AGSb- & 1 & 2 & $\mathrm{AGCe}-$ & 1 & 2 & AGU- & 1 & 2 \\
\hline$g_{2} \mathrm{O}$ & 0.025 & 0.025 & $\mathrm{Ag}_{2} \mathrm{O}$ & 0.025 & 0.025 & $\mathrm{Ag}_{2} \mathrm{O}$ & 0.025 & 0.025 & $\mathrm{Ag}_{2} \mathrm{O}$ & 0.025 & 0.025 \\
\hline
\end{tabular}

熔融した結果， $\mathrm{AGV}-2$ および $\mathrm{AGCr}-1$ がわずかに緑 色， $\mathrm{AGCr}-2$ が淡緑色でやや濁り， $\mathrm{AGFe}-2$ がわずか に青色, $\mathrm{AGCo}-1$ が薄い青色, $\mathrm{AGCo}-2$ がコバルト青, AGNi-2 がわずかに灰色に，それぞれ着色した以外は， すべて無色のガラスとして得られた。AGO のみは銀の みを加えて補助剂を添加せず, 対象試料として熔融し t。.

これら試料の銀および多原子価元素の添加量を決定す るために，あらかじめ，基礎組成のガラス $100 \mathrm{~g}$ 亿対 乙, $\mathrm{Ag}_{2} \mathrm{O}$ を， 0.200 0.025 g, 補助剤として $\mathrm{SnO}$ を $0.465 \sim 0.0036 \mathrm{~g}$ の範团で加えて, それぞれ添加量の組 合わせの異なる 20 種のガラス試料とし, 紫外線照射, 熱処理等㸚おこなって，銀による着色の程度を調べた。 その結果, $\mathrm{Ag}_{2} \mathrm{O}$ の添加量が $0.10 \mathrm{~g}$ 以上では, 急冷し たガラス試料に，すでに着色がみとめられ，結局，紫外 線照射の效果在明らかにするためには， $\mathrm{Ag}_{2} \mathrm{O}$ の添加量 は $0.025 \mathrm{~g}$ の程度が，また $\mathrm{SnO}$ の量はグラム原子の比 にして Sn/Ag の值が 0.25〜0.50 位の範囲が適当であ るとみとめられた。したがって， $\mathrm{Ag}_{2} \mathrm{O}$ の添加量を全体 を通じて $0.025 \mathrm{~g}$ 亿，また補助剤としての多原子洒元 素の添加量を，グラム原子比にして 0.25 および 1.00 と きめ, $\mathrm{SnO}$ は 0.125 および 0.500 の值をえらんだ。

ガラス試料はすべて嬮さ $1 \mathrm{~mm}, 7 \mathrm{~mm} \times 10 \mathrm{~mm}$ の短冊 形に成形し，分光透過率を測定したのち，つぎのような 然理を活どこした。

紫外線照射——ツダ超高圧水銀灯を用いて，管球の 中心から $3 \mathrm{~cm}$ の距離で 5 時間, 紫外線を照射する.乙 の照射により，試料はやや黄色に着色するが，透過率曲 線には明らかな変化在みとめない程度であり, 熱処理に よって，すみやかに螁色する。

子備熱処理一一試料を $800^{\circ} \mathrm{C}$ 亿 10 分間保ったのち急 冷する。この加熱により試料は変形するので, あらかじ わ, やや大形のものを用い, 加熱して急冷後, あらため て成形し, 分光透過率測定および再度の熱処理を抢てな った。

熱処理一一試料を $650^{\circ} \mathrm{C}$ 亿 10 分間保ったのち, 2 時 間で $400^{\circ} \mathrm{C}$ まで温度を等速で下降したのち, 炉外に落 下させて急冷する。

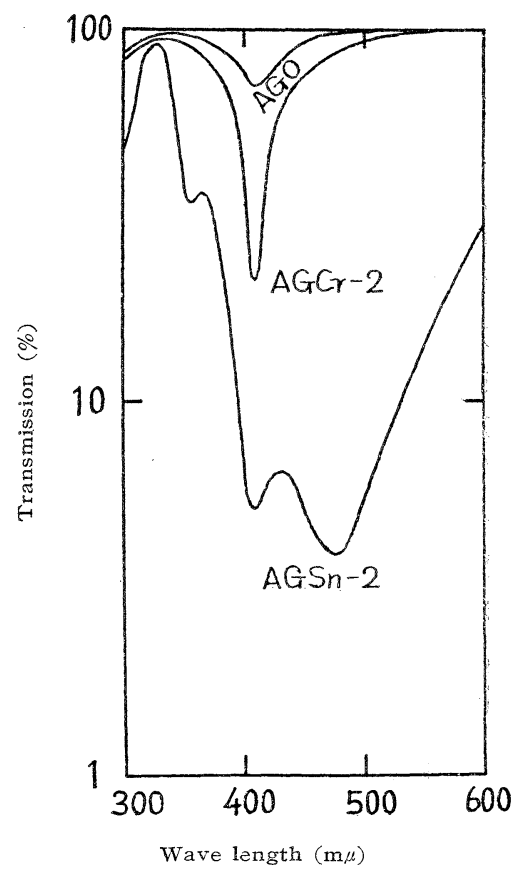

Fig. 1. Transmission curves of specimens given the heat treatment.

以上の 3 種の処理を組合わせてほどしした，つぎの4: 組の試料について分光透過率を測定した。

A) 熱処理した試料：

この熱処理によって，す べての試料は黄色に発色し た.との場合の透過率曲線 そおける吸收ピークほ, 図 -1の $\mathrm{AGO}$ および $\mathrm{AGCr}$ $-2 の$ 透過率曲線にみるよ うに, $410 \mathrm{~m} \mu$ 附近にあ。 て, この発色が, ガラス中 に析出した微細な金属銀の 結晶によるととをあらわし ている(0). 表一1 の全試料 の大部分は図-1 のAGO， つまり補助剤を全く加壳な い銀含有ガラスの試料とほ
Table 2. Values ( $\%$ ) of the lowest transmission about the wave length, $410 \mathrm{mit}^{\prime}$ concerning specimens given the heat treatment.

\begin{tabular}{lcc} 
Specimen & 1 & 2 \\
AGO & \multicolumn{2}{c}{70} \\
AGTi- & - & 67 \\
AGV- & 71 & 77 \\
AGCr- & 73 & 22 \\
AGMn- & 63 & 78 \\
AGFe- & 74 & 78 \\
AGCo- & 67 & 83 \\
AGNi- & - & 75 \\
AGSn- & 65 & $3.9^{*-}$ \\
AGSb- & 66 & 72 \\
AGCe- & 70 & 77 \\
AGU- & 59 & 77
\end{tabular}

$59-77$ 
乙んぞ同一の透過率曲線を示し, 見かけ上, 補助剈の効 果がみとめられなかった。すなうち, 各試料の分光透過 率曲線の $410 \mathrm{~m} \mu$ 附近にある吸収ピークの先端の透過率 (\%)を表-2 にかかげる.

これらのうち， AGCr-2と AGSn-2 とは図-1 亿み るようにあきらか同 $\mathrm{AGO}$ のそれとは異なった曲線を もち,色調も, AGCr-2 は黄色が濃く、また AGSn-2 侍, 吸收ピークが 3 個に分かれていて, 濁った橙色を呈 し，明瞭に補助剂添加の効果がみられた。

\section{B）紫外線照射後, 熱処理した試料 :}

全武料に紫外線照射をほどてしたのち，前と同じ方法 で熱処理した。紫外線照射 Table 3. Values (\%) of the のみによる透過率曲線の変 化はほほとん゙みとめなれ なかったが，末照射試料に みられた AGCe-1，2の $315 \mathrm{~m} \mu$ 附近の吸収 ピクおよび AGU-2 の 260 $\mathrm{m} \mu$ 附近の吸收ピークは, ともに消失していた。熱処 理後の各試料の銀析出によ る吸収ピークの先端の值を 表一3 亿示す・てれらのう ち, 図一2のように, AGFe $-1, \mathrm{AGCe}-1, \mathrm{AGCr}-2$,

lowest transmission about the wave length, $410 \mathrm{~m} \mu$ concerning specimens given the heat treatment after the in radiation of U.V. rays.

\begin{tabular}{lcc} 
Specimen & 1 & 2 \\
AGO & \multicolumn{2}{c}{60} \\
AGTi- & - & 59 \\
AGV- & 74 & 77 \\
AGCr- & 66 & 22 \\
AGMn- & 70 & 66 \\
AGFe- & 22 & 5.7 \\
AGCo- & 55 & 56 \\
AGNi & - & 51 \\
AGSn- & 75 & $\sim 0$ \\
AGSb- & 64 & 30 \\
AGCe- & 35 & 1.2 \\
AGU- & 59 & 58
\end{tabular}

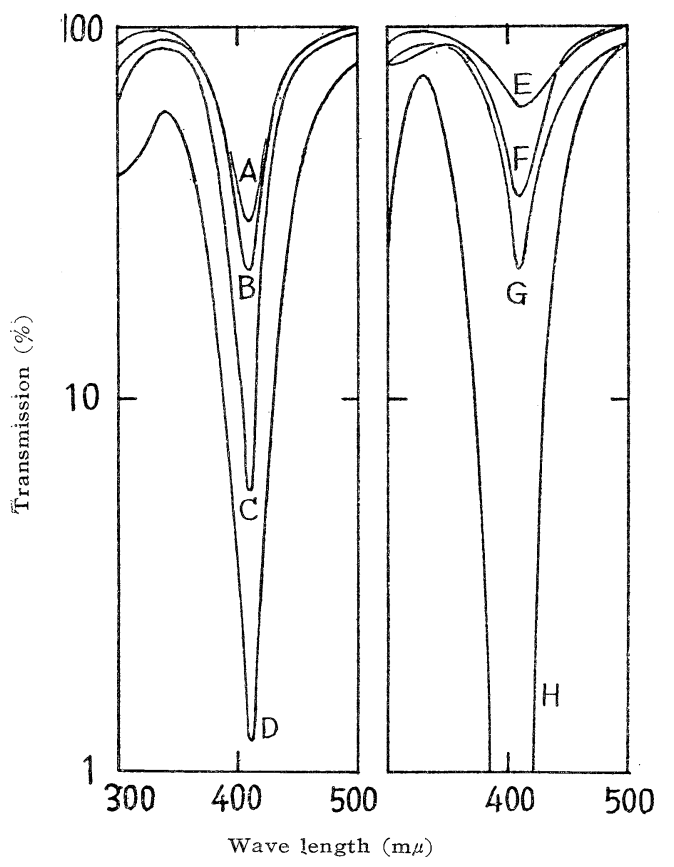

A) AGSb-2, B) AGFe-1, C) AGFe-2,D) AGCe-2 E) AGO, F) AGCe-1, G) AGCr-2, H) AGSn-2

Fig. 2. Transmission curves of specimens given the heat treatment after the irradiation of U.V.-rays.
$\mathrm{AGFe}-2, \mathrm{AGSn}-2, \mathrm{AGSb}-2, \mathrm{AGCe}-2$ の 7 個の試料 の吸収ピークは，AGO のそれに比して，あきらかに深 く, AGCr-2 以外は, 図一1 の同じ試料のそれと比較し て, 紫外線照射の效果力明瞭にみとめられた.とくに AGSn-2 では図-1 のそれに比してピークの形が鋭く，

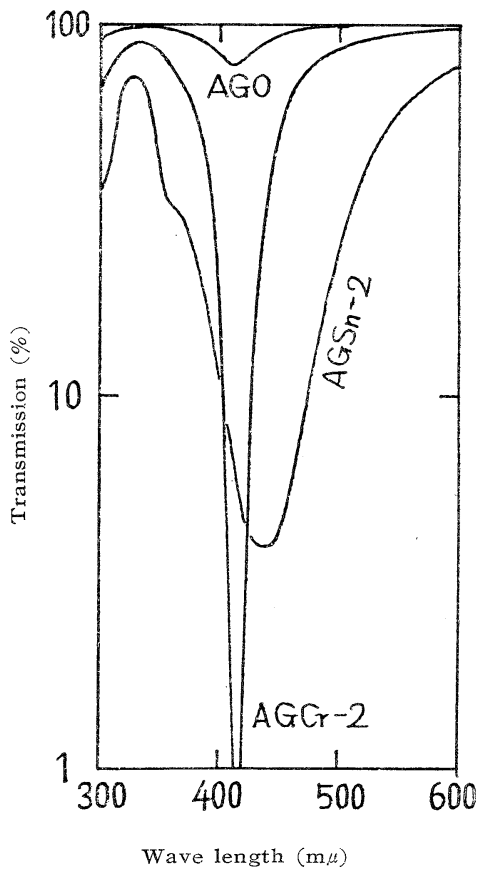

Fig. 3. Transmission curves of specimens given the previous heat treatment.

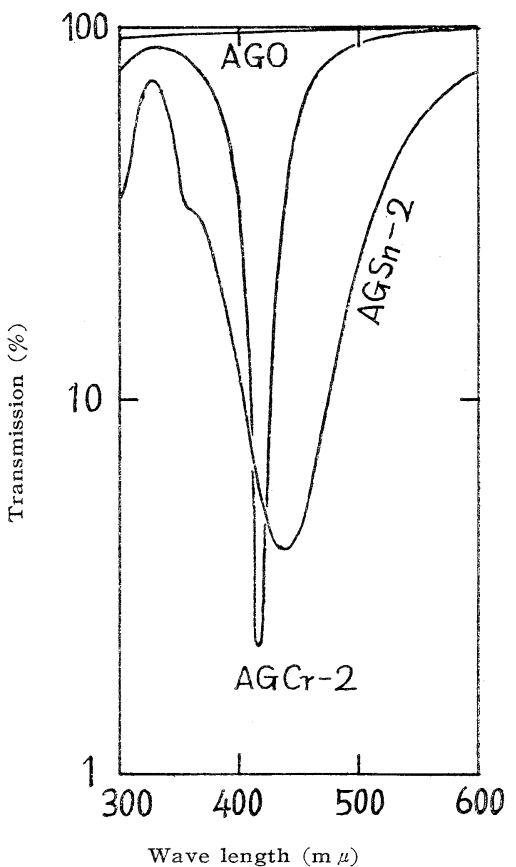

Fig. 4. Transmission curves of specimens given the heat treatment after the previous heat treatment. 
曲線の形にも大きな変化があらわれている。乙れら以外 の試料は AGO のそれと比較して著しい差かなかった。

\section{C) 予備熱処理した試料 :}

全試料学 $800^{\circ} \mathrm{C}, 10$ 分間, 熱弅理した. その結果, 大 部分の試料には発色がみられず，原試料にくらべてな んらの変化もおてらなかったが， AGSn-2 と AGCr-2 は, それぞれ前者は濁った黄色, 後者は透明な黄色の発 色をみた。それらの透過率曲線を図一3，にしめす。

\section{D）予備熱処理後，熱処理した試料：}

予備熱処理した試料を再び所定の方法で熱処理をおこ るった・との結果を表一4 Table 4. Values (\%) of the 飞示す. AGCr-2 亿予倩 熱処理の効果が方とられ た・また AGSn-2 も単に 熱処理のみをしたものとは 異なっているが，てれは図 一ーに示した子予備熱処理の みによる発色と, その透過 率曲線にほとんど差がな い. 他の試料は, すべて黄 色在旺したが，その透過率 曲線は，予備熱処理を省い た場合とほとんど同一で， とくに補助剤添加の効果は みとめられなかった。とれ らの結果を図一4にしめす.

\section{III. 突験結果の考察}

こてに得られた実験結果に対して若干の定性的な考察 を加えよう・まず，ガラス中における銀の析出現象は， その過程を図一5 のように図式的に分けて若えるととが できるであろう。

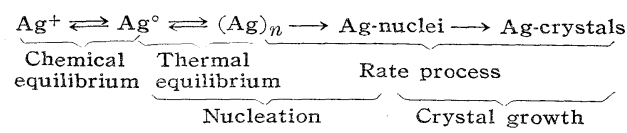

Fig. 5. A schematic representation of the colour-developing process in silvercontaining glasses.

すなわち, 熱処理温度に適当な温度範囲で, ガラス中 に，ある濃度で存在している銀原子， $\mathrm{Ag}^{\circ}$ か熱運動によ って互に衝突して結合し，あるいは，それか洅び解離し て, 平衡的に Embryo を形成し，それらのうちのいく らかがゆらぎによって臨界值以上の大きさに成長して 結晶核となり, 結晶成長の速度過程に入る。この場合に， 出発点として, ガラス中に, ある濃度比で $\mathrm{Ag}^{+}$と $\mathrm{Ag}^{\circ}$ が共存しており, $\mathrm{Ag}^{\circ}$ の濃度が大きいる゙, 結晶核生成 の速度も大きくなって，見加上，発色か速くなる。さ て，銀含有ガラスに多原子洒元素を添加すると，それが

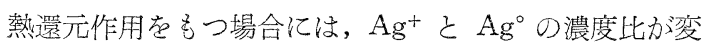

えられて，熱処理時における $\mathrm{Ag}^{\circ}$ の濃度が高められ， 発色速度が上昇するものと考えられる。

本実験の範团内では，Cr，Co および Sn の各イオン が熱処理によって, 乙の効果をあらわし, Cr, Fe, Sn, $\mathrm{Sb}$ 抢よび Ce の备イオンか;, 紫外線照射によって, や はりガラス中の $\mathrm{Ag}^{\circ}$ の濃度を増す効果のあるととがわ かった・一般には前者を熱還元剤 (Thermoreducing agents), 後者を増感㘊 (Sensitizer) とよんでいる。し かし，結局は両者ともに，たと党ば

$$
\mathrm{Ag}^{+}+\mathrm{M}^{+} \rightarrow \mathrm{Ag}^{\circ}+\mathrm{M}^{2+}
$$

のように, 多原子価元素 $\mathrm{M}$ の原子価か滈くなって, 銀 イオンが嚼されると考えられている(5)・しかし，そと にいたるまでの過程に関しては現在まで，活とんど説明 がこてろみられていない.たとえば Stookey にしても， 熱還元剤の作用については，ガラスの冷却過程あるいは 再加熱時に，還元剤を加えたのと同様の作用をすると説 明しているにすぎない(14)。

さて，ガラス中に扑て銀は主として $\mathrm{Ag}^{\circ} と \mathrm{Ag}^{+}$の $2 つ 0$ 状態で共存し，その平衡関係は温度に依存して， 高温に须いては $\mathrm{Ag}^{\circ}$ の濃度増加すると考えられてい $ろ^{15)}$. しかし, 急冷試料では, ガラスの熔融温度にらか い高温の状態がそのまま凍結されていると考えられるか ら，それより低い熱処理温度範囲では， $\mathrm{Ag}^{\circ}$ の濃度は， むしろ減少の傾向を示さなくてはならない。したがっ て，乙の傾向に反して，熱処理時に，なお（1）式のよう な還元反応がおこり得るためには，つぎのような仮定を おくことは妥当であろう・すなわち, 本実験で熱還元作 用をあらわしたような多原子価元素もまた，ガラス中で は2 種以上の原子価のイオンとなって共存しており，そ の平衡関係は, 高温になるにしたがって低原子価イオン の濃度か増加する方向に変じ，したがって，熱処理温度 範囲では，高原子洒イオンの濃度か增大しようとする強 い傾向を生じ，乙のために (1) 式の還元反応か進行する と教えるのである.また多原子価元素のうちで熱還元作 用を示さないか, あるいは示しても微弱であったもの は, 前記平衡関係の温度依存性が, 銀のそれに比して小 さいか, あるいは大差がなく、したがって, $\mathrm{Ag}^{+}$に対し て与えられる価靁子の数が少いと考えれば説明されよ う.

また，增感剤の作用に関しては，常温における紫外線 照射によって,ガラス中で,たとえば

$$
\mathrm{Ag}^{+}+\mathrm{Ce}^{3+}+h \nu \rightarrow \mathrm{Ag}^{\circ}+\mathrm{Ce}^{4+}+* \cdots
$$

のような光化学反応をおてすと考えられている5 式は紫外線の光量子のエネルギー, $h$ עによって, $\mathrm{Ce}^{3+}$ から 1 個の価電子か遊離し， $\mathrm{Ag}^{+}$に捉えられて，乙れ 還元することをあらわし，*印は過剩エネルギーを意 味している.しかし, 常温におけるこの反応惴イオン の衝突によっておこるものではなく, 電子の移動のみに 
よるものであって，常温では睘元されて生じた $\mathrm{Ag}^{\circ} の$ 周囲の局部的な構造に大きな変化は㧍てり得ないから， 比較的高いエネルギーをもっていて，不安定であるが， 熱処理温度範囲で加熱されれば，短時間で安定化する。 このことは電子を放ったセりウム・イオンについても同 じとがえる。

結晶化過程に参加する $\mathrm{Ag}^{\circ}$ の数が多ければ，それだ け発色速度は大きくなるが，その濃度の時間的推移によ って, 結晶核生成に 2 種の型のあるととか洘えられる. すなわち 第一の型は Homogeneous nucleation ${ }^{9 \text { 16) }}$ で, 熱処理温度の蜘囲に保たれている間, 継続的に $\mathrm{Ag}^{+} の$ 還元反応が准行して $\mathrm{Ag}^{\circ}$ 在生じつづける場合であって， 本実験の熱処理過程に扔ける熱還元作用による場合がて れに相当する。したがって，個々の結晶は，その結晶核 生成の時点在異にするから, 結晶の粒度は広範团に分布 し,その結果, 結晶化か進行するにしたがって, 吸收ピ 一クの位置は移動し, かつ透過率曲線の形は大きな変化 右示すようになる。この例は図一1，図一3 および図一 4 の AGSn-2 にみられる。

第二の型は Heterogeneous nucleation ${ }^{916)}$ で, 紫外 線照射後の熱処理による発色にみられ，熱処理の初期に $\mathrm{Ag}^{\circ}$ の濃度が最大值を示し, それ以後の熱還元による $\mathrm{Ag}^{\circ}$ の生成が無視できる場合で, 各結晶の粒度は活とん ぞ等しいから, 吸収ピークは単純な形を保ち, その位置

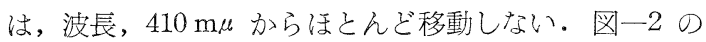
AGCe-2, AGSn-2 などその例である. 後者は, 紫外線 照射による光化学的還元か相当程度おてなわれているの で, 熱処理時の熱還元作用の寄与か心㲺さく, 透過率曲線 の吸取ピークか鋭く深くなったものであろう.

最後に, $800^{\circ} \mathrm{C}$ でおてなった予傹熱処理によって, と くに AGCr-2 に著しい効果がみとめられたが，このも のの透過率曲線における特長は, 吸収ピークが細く鋭 く, ピークの位置も $415 \mathrm{~m} \mu$ で, その偏りがきわめて小 さい点にある・とのととは結晶核生成が Heterogeneous nucleation に近いととを意味していると考光られる。

\section{IV. 総 括}

銀含有ガラス中からの銀の結晶析出現象において, と くにその発色に求よぼす補助剤としての多原子洒元素の 影響について調べた。銀を含む $\mathrm{Na}_{2} \mathrm{O} 18.0, \mathrm{CaO} 8.5$, $\mathrm{Al}_{2} \mathrm{O}_{3} 1.5, \mathrm{SiO}_{2} 72.0$ （\%）なる基礎組成に対して, $\mathrm{Ti}$, $\mathrm{V}, \mathrm{Cr}, \mathrm{Mn}, \mathrm{Fe}, \mathrm{Co}, \mathrm{Ni}, \mathrm{Sn}, \mathrm{Sb}, \mathrm{Ce}, \mathrm{U} の 11$ 種
類の多原子佂元素を, 酸化物その他の化合物として, そ れぞれ 2 水準の添加率で加えて, 試料ガラスとした。

これらに対して，1） $650^{\circ} \sim 400^{\circ} \mathrm{C}$ 間の温度下降による 熱処理，2）紫外線照射，3） $800^{\circ} \mathrm{C}, 10$ 分の予備熱処理, の3 種の処理を組合わせて施し, 発色した試料の250〜 $750 \mathrm{~m} \mu$ の波長範网における分光透過率を測定し, 同一 処理を施した添加剤を加えない試料のそれと比較した。

実験の範囲内で, $\mathrm{Cr}, \mathrm{Co}, \mathrm{Sn}$ の各イオンか熱妈理時 の発色 亿対して有效に作用し, $\mathrm{Cr}, \mathrm{Fe}, \mathrm{Sn}, \mathrm{Sb}, \mathrm{Ce} の$ 各イオンが，発色に対して紫外線照射を有效ならしめる 作用があった。しれらの効果は, 熱処理時における原子 状態の銀, $\mathrm{Ag}^{\circ}$ の濃度を高めるととに起因すると考えら れる.すなおち，ガラス中の銀および次式に (M) で示 す多原子価元素に，それぞれたとえば

$$
\begin{aligned}
& \mathrm{Ag}^{\circ} \rightleftarrows \mathrm{Ag}^{+} \\
& \mathrm{M}^{+} \rightleftarrows \mathrm{M}^{2+}
\end{aligned}
$$

等のような平衡関係があり，その平衡定数が，ともに温 度に依存し, その依存の程度の差によって, Thermoreducing agentないし Sensitizer としての作用が㧍こ なわれると考えて, 多原子価元素の効果を説明した。

なお, 本研究は昭和 33 年度, 文部省科学研究費の各個研究費 を利用しておこなった。

最後に, 本研究に終始, 適切な示唆をたまわった東京工業大 学, 森谷太郎教授に衰心から謝意学表する次第である。

\section{参 照 文 献}

1）境野照雄, 工化，63 [7] 1104 (1960］

2）森谷太郎, 境野照雄, 才野 浩, 滝沢一貴, 㸃協, 68 [772] 103 (1960)

3）安部俊夫, 窝協, 68 [776]C 291 (1960)

4) W.A. Weyl, Coloured Glasses, p. 344 (1951), Soc。 Glass Tech., Sheffild, England.

5) S.D. Stookey, Ind. Eng. Chem., 41 [4] 856 (1949)

6) W.A. Wey1, Coloured Glasses, p. 348 (1951)

7) S.D. Stookey, J. Am. Ceram. Soc., 32 [8] 246 (1949)

8) W.A. Weyl, Coloured Glasses, p. 343 (1951)

9) R.D. Maurer, J. Appl. Phys., 29 [1] 1 (1958)

10) R. Yokota, K. Shimizu, J. Phys. Soc. Jap., 12, 833 (1957)

11) T. Sakaino, T.N. Sharma, T. Moriya, Bull. Tokyo Inst. Tech., Ser-B, [3] 212 (1956)

12) L. Riedel, E. Zschimmer, Keram. Rund., 37 [12, $14,16,32,34,37](1949)$

13）沢井郁太郎，久保郁三，工化，40［3] 172 (1937)

14) S.D. Stookey, J. Am. Ceram. Soc., 32 [8] 246 (1949)

15) W.A. Weyl, Coloured Glasses, p. 332 (1951)

16) J.C. Fisher, J.H. Hollomon, D. Turnbull, J. Appl. Phys., 19 [8] 775 (1948)

$(8 / 22 / 60$ 受淤 $)$ 